\title{
Mesleki Eğitim Merkezine Devam Eden Ergenlerin Kural Dışı Davranış Düzeylerinin İncelenmesi
}

\author{
Examining Delinquent Behavior Levels of Teenagers Continuing Vocational \\ Training Centers
}

\author{
Diler AYDIN*, Esra KARACA ÇİFTÇi**
}

İletişim/Correspondence: Diler AYDIN Adres/ Address: Balıkesir Üniversitesi, Bandırma Sağlık Yüksekokulu, Çocuk Sağlığı ve Hastalıkları Hemşireliği AD., 10200, Bandırma/ Balıkesir Tel: 02662138866 Fax: 02667186414 E-mail: dileraydin@gmail.com

\begin{abstract}
$\ddot{O} Z$
Amaç: Mesleki eğitim merkezine devam eden ergenlerin kural dışı davranış düzeylerine etki eden etmenlerin incelenmesi amaçlandl.

Yöntem: Araştırma bir mesleki eğitim merkezine devam eden ve çalışmaya katılmayı kabul eden 105 ergen ile Mart-Nisan 2014 tarihleri arasında yapıld. Kişisel bilgi formu ve Kuraldışı Davranış Ölçeği (KDÖ) kullanılarak elde edilen veriler sayl ve yüzdelik, ki-kare, Kruskal-Vallis ve Mann-Whitney U testleri ile değerlendirildi.

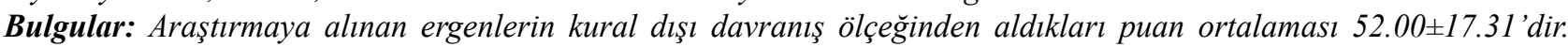
Ergenlerin sıklıkla başvurduğu kural dışı davranışlar arasında; yasaların izin vermediği araçları kullanma (\%22.9), araç kullanırken hız limitini aşma (\%16.2), alkollü içkiler içme (\%15.2), kavga etme (\%13.3), kavgaya katılma (\%12.4), eşyaları kırma (\%11.4), sinavlarda fisıldama (\%10.5), sinavlarda kopya çekmek (\%9.5) ve okuldan kaçma (\%6.7) gibi davranışların olduğu belirlendi. Araştırmadan elde edilen sonuçlara göre; kural dışı davranışı puan ortalamaları ile ergenin cinsiyeti, alkol ve madde kullanım durumu arasında istatiksel anlamlılık görüldü $(p<0.05)$.
\end{abstract}

Sonuç: Risk altındaki ergenlerin kural dışı davranış içeren davranışlarda bulunmasının önlenmesinde bu risk faktörlerinin kontrol altina alınmasi gereklidir.

Anahtar Kelimeler: Kural dışı davranış, ergenlik, risk faktörü.

\section{ABSTRACT}

Aim: The aim of the study is to examine delinquent behavior levels of teenagers attending vocational training centers.

Method: The study was conducted with 105 adolescents attending a vocational training center who accepted to participate the research between March-April 2014. Data obtained using personal information form and Delinquency Scale was evaluated by using percentages, chi-square, Kruskal-Wallis and Mann-Whitney U testing.

Results: The mean score of adolescents in the delinquency scale was 52.00 \pm 17.31 . Frequently committed delinquent behaviors among adolescents are as follows: Using vehicles prohibited by the law (22.9\%); exceeding the operating speed limit (16.2\%); consuming alcoholic beverages (15.2\%); fighting (13.3\%); joining a fight (12.4\%); breaking appliances (11.4\%); whispering in exams (10.5); cheating in exams (9.5\%) and escaping from school (6.7\%). According to the results obtained from the research, statistical significance was observed between alcohol and substance use and gender of the teenager and illegal behavior average score $(p<0.05)$.

Conclusion: Teenagers attending vocational education centers work and they are in more risky environments than other teenagers. Risk factors have to be identified, families and schools have to collaborate to eliminate these risk factors.

Keywords: Adolescent, delinquent behaviour, risk factors.

*Yrd. Doç. Dr. Balıkesir Üniversitesi Bandırma Sağllk Yüksekokulu Hemşirelik Bölümü, **Yrd. Doç. Dr. Zirve Üniversitesi Să̆llk Bilimleri Fakültesi Hemşirelik Bölümü

Yazının gönderilme tarihi: 05.02.2015

Yazının basım için kabul tarihi: 22.04.2016 


\section{GíRiş}

Ergenlik kavramı 19. yüzyılın sonunda ve 20. yüzy1lın başlarından beri çocukluk ve yetişkinlik arasında duygusal ve fiziksel gelişim aşısından kendine has problemleri olan bir dönemi tasvir etmek için kullanılmaktadır (Ögel 2014).

$\mathrm{Bu}$ dönem ergenin hem toplumsal nitelik kazandığı, hem de kişiliğini kazandığı bir arayış dönemidir. Ergen, değişen ve gelişen kişiliği içinde çevrede yeni değerler aramaya, kişiliğinin olgunlaşmasında rol oynayan özdeşleşme, özerklik, sorumluluk kavramlar1na yanıt bulmaya çalışır. Bu arayışın özünde topluma uyum sağlama isteği ve onay görme gereksinimi yatmaktadır (Akduman, Akduman ve Cantürk 2007). Gelişimsel özelliklerindeki değişimlerin yanında, ergenin iyilik halini tehdit eden kural dışı davranışları gösterme eğiliminde artış gözlenmektedir (Ateş ve Akbaş 2012; Bulut 2010; Önder ve Yılmaz 2012). Çocuk ve gençlerde kural dışı davranış ergenlik döneminin doğal bir özelliği olarak görülerek bu yaş grubundaki bütün gençlere mal edilmiştir. Araştırmada, kural dışı olarak adlandırılan davranışlar, farklı araştırmalarda risk, problem, anormal, sapan, suç davranışı olarak tanımlanmaktadır. Kural dışı davranış en yaygın olarak ergenlik öncesi ve erken ergenlik döneminde başlayarak, ergenlik döneminin sonuna doğru en yüksek seviyeye ulaşıp, yetişkinliğe geçilmesiyle beraber düşüşe geçmektedir (Ögel 2014).

Kural dışı davranışın ortaya çıkışı ile ilgili çocuk ve ergenlerle yapılan araştırmalarda, kişisel, sosyal ve toplumsal faktörlerin hepsinin bu tür davranışların ve suç işleme eğiliminin oluşumunda etkisi olduğu bilinmektedir. Ergenlerde kural dışı davranışlar doğum öncesi dönemden başlayarak bütün yaşam süresi boyunca, kişisel, biyolojik, genetik ve çevresel faktörlerin karmaşık etkileşimlerinin sonucu olarak karşımıza çıkmaktadır (Akduman ve Baran 2010; Güler 2010; Korkmaz ve Erden 2010; Ögel 2014; Wasserman ve ark. 2003). Bu dönemde çocuk veya ergenin deneyimlediği risk faktörleri arttıkça kural dışı davranış işleme ihtimalinin de arttığı bilinmektedir. Çocuklarda kural dışı davranışlar çocuğun yaşının ilerlemesi nedeniyle toplum için ciddi sorunları da içinde barındırmasından dolayı "kaygı verici” olarak değerlendirilir (Ögel 2014; Önder ve Y1lmaz 2012; UN 2003).

Ergenlerde görülen kural dışı davranışlar kasıtsız olarak yaralanmalar (emniyet kemeri takmamak, alkollü araba kullanmak vs.) ve şiddete (silah taşımak, kavgaya karışmak) (Canbulat ve Yıldız 2011) neden olan davranışlar, tütün, alkol ve uyuşturucu madde kullan1m1, riskli cinsel davranışlar, sağlıksız beslenme alışkanlıkları, fiziksel hareketsizlik, evden ya da okuldan kaçma, yalan söyleme, hırsızlık, depresyon, intihar, anti-sosyal davranışlar olarak sayılabilir (Ateş ve Akbaş 2012; Önder ve Y1lmaz 2012; Türkiye'de Ergen Profili 2008). Bu dönemde sık görülen kural dışı davranışların ergene kendi yaşamını kontrol edebilme, yetişkin otoritesine ve geleneksel topluma karşı açıkça karşı koyma, akran grubuna kabul edilme, kaygı, engellenme, yetersizlik ve başarısızlıkla baş etme gibi kazanımlar sağlayabilmektedir (Ateş ve Akbaş 2012; Bulut 2010; Önder ve Yılmaz 2012). Ayrıca kural dış1 davranışlar, ergenlerin günlük yaşama uyumunu zorlaştırmakla birlikte uzun vadede ergenin hem fiziksel hem de ruhsal sağlığında ciddi olumsuz sonuçlara yol açabilmekte, ergenin gelişim görevlerini başarmasına, kendisinden beklenen sosyal rolleri yerine getirmesine, yeterlik ve başarı duygusunu hissetmesine ve genç yetişkinlik dönemine başarıyla geçmesine engel olabilmektedir (Önder ve Yilmaz 2012).

Literatürde ergenleri kural dışı davranışlara iten nedenler değerlendirildiğinde bireysel özelliklerinin yanında toplumsal özellikleri, ergenlerin kişisel özellikleri, ailesel ve çevresel özellikleri olarak gruplandırılmaktadır (Akduman ve ark. 2007; Bal 2010). Ergenlerde kural dışı davranışı anlayabilmek için hem ergenlerin kişisel özelliklerinin, hem de içinde yetiştikleri ailesel özelliklerin belirlenmesi önemlidir.

Ülkemizde çalışan çocukların önemli bir kısmını çırak statüsünde çalışan çocuklar oluşturmaktadır (Arkan 2011). Bu çocuklar bir mesleğe adım atmak amacı ile iş yerlerinde aday çırak olarak görev almakta ve 
eğitimlerine devam etmektedirler (Avşar ve Öğütoğulları 2012). Çocukların çalışma yaşamında erken yer almasının nedenleri çeşitli faktörlere bağlı olmakla birlikte yaşamlarını sürdürmek için çalışmak zorunda olan çocuklar yoksulluk, sağlığı tehdit eden ortamlarda bulunma, eğitim eksikliği, yetersiz beslenme, fiziksel acı ve yorgunluk ve/veya kaza riski, bağımlılık, istismar, şiddetten yoğun olarak zarar görmekte ve kural dış1 davranışlar nedeniyle suça yönelebilmektedirler (Turla, Tomak ve Pekşen 2009).

Mesleki eğitim merkezindeki adölesanların çalışmalar1 ve diğer adölesanlara göre daha fazla riskli çevrede olmaları düşüncesinden hareket edilerek planlanan bu çalışma; Mart-Nisan 2014 tarihlerinde bir mesleki eğitim merkezine devam eden ergenlerin kural dışı davranış düzeylerine etki eden etmenlerin incelenmesi amaciyla yapıldı.

\section{YÖNTEM}

\section{Araştırmanın Tipi}

Araştırma tanımlayıcı ve kesitsel tiptedir.

\section{Araştırmanın Evreni ve Örneklemi}

Araştırmanın evrenini Bandırma'da mesleki eğitim merkezinde öğrenim gören ve 14-19 yaş grubunda olan toplam 150 öğrenci oluşturmaktadır. Araştırma verilerinin toplandığ tarihlerde öğrencilerden bir kısm1nın merkeze gelmemeleri nedeni ile ulaşamama veya araştırmaya katılmayı kabul etmeme gibi nedenler ile araştırma 105 öğrenci ile yürütülmüştür.

\section{Veri Toplama Araçları}

Araştırmada veriler, "Ergen/Kişisel Bilgi Formu" ve "Kuraldışı Davranış Ölçeği (KDÖ)” ile birebir görüşme tekniği kullanılarak toplanmıştır. Her görüşme 15-20 dk sürmüştür. Anket formu iki bölümden oluşmaktadır.

Araştırma ve ergenlerin kuraldışı davranışlarını ölçmek amaciyla Kaner (2001a) tarafindan geliştirilen KDÖ kullanılmıştır.
Çocuk Tanılama Formu: Birinci bölümde, araştırmac1 tarafindan ergenlerin ve ailelerinin sosyo-demografik nitelikleri hakkında veri toplamak için literatüre (Akduman ve ark. 2007; Balkaya ve Ceyhan 2007; Özen, Ece, Oto, Tirasçı ve Gören 2005; Şahin 2013) dayanılarak hazırlanan Ergen/ Kişisel Bilgi Formu kullanılmıştır. Ergen/ Kişisel Bilgi Formun'da mesleki eğitim merkezinde eğitim gören ergenlerin cinsiyet, yaş, sosyoekonomik düzey, anne-babanın öğrenim durumu, çalışma durumu, anne babanın birliktelik durumu, sigara, alkol ve madde kullanma durumu, istismar türlerinden birine maruz kalma durumu (sözel ifadeleri doğrultusunda) ve daha önce adliyeye sevk edilmesi gereken herhangi bir suç davranışı işleme durumunun sorgulandığı sorular yer almaktadır.

Kuraldışı Davranış Ölçeği (KDÖ): KDÖ, Kaner (2001a) tarafindan ergenler arasında resmi kurumlara yansımayan, ancak yakalanmış olsalardı çoğu suç olarak kabul edilecek ve ergeni yasalarla karşı karşıya getirecek davranışları belirlemek amacıyla geliştirilmiştir. KDÖ 9 alt ölçek ve 38 maddeden oluşmaktadır. Ölçekte ergenlerin okuldan kaçma, yasaların kullanmanıza izin vermediği otomobil, motosiklet vb taşıt araçlarını kullanma, uyuşturucu maddeleri kullanma, kavgaya karışma, hırsızlık yapma vb kural dışı davranış işleme durumları sorgulanmaktadır. Ergenlerden, maddelerde yer alan davranışlarını son 6 ay içinde gösterme sıklıklarını "4-5 kez ya da daha fazla, 3-4 kez, 1-2 kez, Hiçbir zaman” şeklinde belirtmeleri istenmiştir. Ölçekten alınabilecek en yüksek puan 152, en düşük puan ise 38 'dir. Ölçekten yüksek puan almak, istenmeyen davranışların çokluğunu göstermektedir (Kaner 2001a; Kaner 2001b). Testin, Cronbach alfa güvenilirlik katsayısı 0.93 olarak belirtilmiştir. Bizim çalışmamızda ise ölçeğin alfa değeri 0.93 olarak bulunmuştur. KDÖ alt boyutları araştırmanın analizlerinde kullanılmamış yalnızca toplam puan üzerinden değerlendirmeler yapılmıştır.

Verilerin toplanmasında Bandırma İlçe Milli Eğitim Müdürlüğü’nden gerekli yazılı izinler (26153647/900) ve öğrencilerden sözlü onam alınmıştır. Verilerin değerlendirilmesinde ise SPSS 16.00 paket programında sayı yüzdelik, Kruskal-Vallis ve Mann-Whitney U testleri ile değerlendirilmiştir. 


\section{BULGULAR}

Araştırmaya alınan ergenlerin \%80'inin erkek, \%20 'sinin kız olduğu ve yaş ortalamasının $17.64 \pm 1.29$ olduğu belirlenmiştir. Araştırmaya alınan ergenlerin $\% 49.5$ 'inin annesinin ilkokul mezunu ve \%84.8'inin ev hanımı olduğu, babaların ise \%52.4'ünün ilkokul mezunu ve \%47.6'sının işçi olduğu belirlenmiştir.

Ergenlerin \%54.3'ünün iki, \%23.8'inin üç kardeşe sahip olduğu belirlenmiştir. Ergenlerin \%61.9'unun sosyal güvencesinin olduğu, \%38.1'inin sosyal güvencesinin olmadığ 1 ve \%93.3'ünün çırak olarak çalişmaktan memnun olduğu saptanmıştır. İş değişikliği yapmayıp devamlı aynı işte çalışanların oranı \%64.8, ikiden fazla iş değişikliği yapanların oranı \%15.2 olarak belirlenmiştir. İş değişikliği yapanların $\% 54.04$ 'i patronu ile anlaşamadığı, \%24.32'si işi sevemediği için değişiklik yaptıklarını belirtmişlerdir.

Ergenlerin \%62.9'unun sigara ve \%8.6'sının uyuşturucu madde kullandığını ifade etmişlerdir. İstismara maruz kalma durumları sorgulandığında \%38.1'inin istismara türlerinden en az birine (fiziksel, duygusal veya cinsel) maruz kaldıkları belirlenmiştir. Araştırmaya katılan gençlerin \%8.6'sının daha önce adliyeye sevk edilen (uyuşturucu kullanma, bir kişiye zarar vereme vb.) bir suça karıştığı saptanmıştır.

Tablo 1. Ergenlerin KDÖ'de "Beş ya da Daha Fazla Kez" Yaptıklarını Bildirdikleri Bazı Maddelere İlişkin Frekans Dağılımı

\begin{tabular}{|l|c|c|}
\hline Kural Dışı Davranışlar & n & \% \\
\hline $\begin{array}{l}\text { Yasaların kullanmanıza izin vermediği otomobil, } \\
\text { motosiklet gibi taşıt araçlarını kullanmak }\end{array}$ & 24 & 22.9 \\
\hline $\begin{array}{l}\text { Bisiklet, motosikletya da otomobil gibi araçları } \\
\text { hız limitini aşacak şekilde kullanmak }\end{array}$ & 17 & 16.2 \\
\hline $\begin{array}{l}\text { Yasaların kullanmanıza izin vermediği alkollü } \\
\text { içkiler içme }\end{array}$ & 16 & 15.2 \\
\hline $\begin{array}{l}\text { Tartışma sırasında karşısındakini öfkelenerek } \\
\text { dövmek }\end{array}$ & 14 & 13.3 \\
\hline Başkalarının başlattığı kavgaya katılmak & 13 & 12.4 \\
\hline Öfkelendiği zaman eşyaları kırmak & 12 & 11.4 \\
\hline Sözlü ya da yazılı sınavlarda fisıldamak & 11 & 10.5 \\
\hline Sınavlarda kopya çekmek & 10 & 9.5 \\
\hline Okuldan kaçmak & 7 & 6.7 \\
\hline
\end{tabular}

KDÖ alt boyutları araştırmanın analizlerinde kullanılmamış yalnızca toplam puan üzerinde hesaplamalar yapılmıştır. Ancak, bu araştırmada ergenler tarafından daha sık başvurulan davranışları göstermek için ergenlerin Kural dışı davranış ölçeğinde " 5 ya da daha fazla kez" yaptıklarını bildirdikleri bazı maddelere ilişkin frekans dağılımı Tablo 1'de sunulmuştur.

Tablo 1 incelendiğinde araştırmada ergenlerin yasaların izin vermediği araçları kullanma (\%22.9), araç kullanırken hız limitini aşma (\%16.2), alkollü içkiler içme (\%15.2) vb. kural dışı davranışlara sıklıkla başvurduğu görülmektedir.

Tablo 2. Ergenlerin Suç Davranışı Puan Ortalamaları

\begin{tabular}{|c|c|c|c|c|}
\hline $\mathbf{n}$ & $\mathbf{x}$ & $\mathbf{s}$ & En Düşük Puan & En Yüksek Puan \\
\hline 105 & 52.00 & 17.31 & 38 & 152 \\
\hline
\end{tabular}

Tablo 2 incelendiğinde araştırmaya alınan ergenlerin kural dışı davranış ölçeğinden aldıkları puan ortalamas1 52.00, standart sapmas1 17.31 'dir. Ölçekten elde edilen en düşük puan 38 ve en yüksek puan 152'dir.

Tablo 3 incelendiğinde araştırmada cinsiyetlere göre ergenlerin kural dışı davranış puanları değerlendirildiğinde aralarında istatiksel olarak anlamllık saptanmıştır $(p<0,05)$. Erkeklerin kural dışı davranış ölçeği puanlarının (\%54.07) kızların puanlarından (\%43.76) yüksek olduğu görülmektedir.

KDÖ'den elde edilen puan ortalamaları ergenlerin yaşları ile karşılaştırıldığında 14-17 yaş aralığında 53.58, 18-20 yaş aralığında 50.51 olarak bulunmuş ve aralarındaki fark istatiksel olarak anlamlılık saptanmamıştır $(p>0,05)$. Araştırmada ergenlerin kural dış1 davranış puanları anne-babanın beraber olma durumuna göre değerlendirildiğinde aralarında istatiksel olarak anlamlılık saptanmamıştır ( $>00,05)$.

KDÖ'den elde edilen puan ortalamaları ergenlerin sigara kullanma durumlarına göre değerlendirildiğinde aralarında istatiksel olarak anlamlılık saptanmamıştır ( $>0,005)$. Ölçekten elde edilen puan ortalamaları ergenlerin alkol ve uyuşturucu madde kullanma durumlarına göre değerlendirildiğinde istatiksel anlamlılık tespit edilmiştir $(\mathrm{p}<0,05)$. 
Tablo 3. Ergenlerin Bazı Demografik Özellikleri ile KDÖ’den Aldıkları Puanların Karşılaştırılması

\begin{tabular}{|c|c|c|c|c|c|c|}
\hline Demografik Özellikler & Değişkenler & $\mathbf{n}$ & $\begin{array}{c}\text { Sira } \\
\text { Ortalaması }\end{array}$ & $\begin{array}{c}\text { Sira } \\
\text { Toplamı }\end{array}$ & $\mathbf{U}$ & $\mathbf{p}$ \\
\hline \multirow{2}{*}{ Cinsiyet } & Erkek & 84 & 53.08 & 4878.5 & \multirow{2}{*}{455.5} & \multirow{2}{*}{0.001} \\
\hline & $\mathrm{K} 1 \mathrm{z}$ & 21 & 32.69 & 686.5 & & \\
\hline \multirow{2}{*}{ Yaş } & $14-17$ & 51 & 53.24 & 2715.00 & \multirow{2}{*}{1365.00} & \multirow{2}{*}{0.939} \\
\hline & $18-19$ & 54 & 52.78 & 2850.00 & & \\
\hline \multirow{2}{*}{ Anne-babanın beraber olma durumu } & Birlikte & 91 & 53.36 & 5855.5 & \multirow{2}{*}{604.50} & \multirow{2}{*}{0.759} \\
\hline & Ayr1 & 14 & 50.68 & 709.50 & & \\
\hline \multirow{2}{*}{ Sigara kullanma durumu } & Kullaniyor & 66 & 58.43 & 3856.5 & \multirow{2}{*}{928.5} & \multirow{2}{*}{0.017} \\
\hline & Kullanmiyor & 39 & 43.81 & 1708.5 & & \\
\hline \multirow{2}{*}{ Alkol kullanma durumu } & Kullaniyor & 51 & 65.49 & 3340.0 & \multirow{2}{*}{740.0} & \multirow{2}{*}{0.000} \\
\hline & Kullanmiyor & 54 & 41.20 & 2225.0 & & \\
\hline \multirow{2}{*}{ Uyuşturucu madde kullanma durumu } & Kullaniyor & 9 & 82.50 & 742.50 & \multirow{2}{*}{166.50} & \multirow{2}{*}{0.002} \\
\hline & Kullanmiyor & 96 & 50.23 & 4822.50 & & \\
\hline \multirow{2}{*}{ İstismara uğrama durumu } & Uğramış & 40 & 59.31 & 2372.50 & \multirow{2}{*}{1047.50} & \multirow{2}{*}{0.095} \\
\hline & Uğramamış & 65 & 49.12 & 3192.50 & & \\
\hline \multirow{2}{*}{ Suç işleme durumu } & İşlemiş & 9 & 67.22 & 605.00 & \multirow{2}{*}{304.0} & \multirow{2}{*}{0.142} \\
\hline & İşlememiş & 96 & 51.67 & 4960.0 & & \\
\hline
\end{tabular}

KDÖ’den elde edilen puan ortalamaları ergenlerin suç işleme ve istismara uğrama durumlarına göre değerlendirildiğinde aralarında istatiksel olarak anlamlılık saptanmamıştır ( $>00.05)$.

Tablo 4. Eğitim Durumu ve Aile Gelir Durumu ile KDÖ’den Aldıkları Puanın Karşılaştırılması

\begin{tabular}{|c|c|c|c|c|c|}
\hline & & $\mathbf{n}$ & $\begin{array}{c}\text { Sira } \\
\text { Ortalaması }\end{array}$ & sd & $\mathbf{x}^{2}$ \\
\hline \multirow{4}{*}{$\begin{array}{l}\text { Annenin } \\
\text { Eğitim } \\
\text { Durumu }\end{array}$} & $\begin{array}{l}\text { Okula } \\
\text { gitmemiş }\end{array}$ & 11 & 47.91 & \multirow{4}{*}{3} & \multirow{4}{*}{4.321} \\
\hline & İlkokul & 52 & 52.29 & & \\
\hline & Ortaokul & 38 & 52.26 & & \\
\hline & Lise & 4 & 83.25 & & \\
\hline \multirow{4}{*}{$\begin{array}{l}\text { Babanın } \\
\text { Eğitim } \\
\text { Durumu }\end{array}$} & $\begin{array}{l}\text { Okula } \\
\text { gitmemiş }\end{array}$ & 8 & 52.94 & \multirow{4}{*}{3} & \multirow{4}{*}{0.625} \\
\hline & İlkokul & 55 & 50.88 & & \\
\hline & Ortaokul & 35 & 55.93 & & \\
\hline & Lise & 7 & 55.07 & & \\
\hline \multirow{3}{*}{$\begin{array}{l}\text { Aile } \\
\text { Gelir } \\
\text { Durumu }\end{array}$} & İyi & 32 & 45.17 & \multirow{3}{*}{2} & \multirow{3}{*}{4.428} \\
\hline & Orta & 63 & 54.77 & & \\
\hline & Kötü & 10 & 66.90 & & \\
\hline
\end{tabular}

KDÖ'den elde edilen puan ortalamaları anne ve babaların öğrenim durumları ve ailenin gelir durumlarına göre değerlendirildiğinde aralarında istatiksel olarak anlamlılık saptanmamıştır ( $\mathrm{p}>0,05)$.

\section{TARTIŞMA}

Literatürde ergenlerin problemli davranışları araştırılırken kural dışı davranış, riskli davranış, sapan davranış, suç davranışı, anormal davranış ya da antisosyal davranış terimlerinin kullanıldığı görülmektedir (Bal 2010; Şahin 2015). Kural dışı davranışların büyük bir bölümü suç kabul edilebilecek ergeni yasalar ile karş1 karşıya getirecek olan davranışları içermektedir. Suç işleme eğiliminde olan ya da suç işlemiş gençler sosyal normları ve başkalarının haklarını ihlal eden davranışlar ile aile, okul ve akranları ile sorunlar yaşayabilmektedirler. Ergenlerde kural dışı/ suç davranışını anlayabilmek için etkileyen etmenlerin belirlenmesi önemlidir.

Araştırmada ergenlerin kural dışı davranış ölçeğinden aldıkları puan ortalaması 52.00 olarak bulunmuştur. 
KDÖ’den elde edilen en düşük ve en yüksek değerler (38-152) dikkate alındığında ergenlerin suç davranışı düzeylerinin düşük olduğu ifade edilmektedir.

Literatür incelendiğinde erkek cinsiyetinde kural dış1 davranışın daha yüksek olduğu belirtilmektedir (Akduman ve ark. 2007; Balkaya ve Ceyhan 2007; Korkmaz ve Erden 2010). Araştırmada mesleki eğitim merkezine devam eden ergenlerin kural dışı davranış ölçeğinden aldıkları puan ortalamaları cinsiyetlere göre değerlendirildiğinde aralarında istatiksel farklılık gözlenmiştir $(\mathrm{p}<0,05)$. Araştırma bulguları literatür bulguları ile benzerlik göstermektedir. Toplumumuzun sosyal yapısı kız ve erkek cinsiyetleri ve yetiştirilme biçimleri arasındaki farklılıklar ve çalışmamızda kız öğrenci sayısındaki azlığa bağlı olarak cinsiyetler arasında farklılıklara neden olmuş olabilir.

Kural dışı davranışlar en yaygın olarak ergenlik öncesi dönemde başlayarak, ergenlik döneminin sonunda en üst seviyeye ulaşarak yetişkinliğe geçilmesi ile düşüşe geçmektedir (Ögel 2014). Araştırmada mesleki eğitim merkezine devam eden ergenlerin yaşları ile kural dışı davranışları arasında anlamlılık saptanmamıştır. Akduman ve ark. (2007), Balkaya ve Ceyhan (2007), Özen ve ark. (2005) ve Şahin (2013)'nin çalışmalarında ergenlerin yaşları arttıkça kural dışı davranışlarında da artış görüldüğü belirtilmiş olup çalışma bulguları ile uyumluluk göstermemektedir. Ergenlerin yaşları arttıkça özgürlüklerinin artması, ebeveyn denetiminin giderek azalması, bulunduğu arkadaş çevresinin önem kazanması gibi nedenlerden dolayı kural dışı davranışlarında artış görülmesine neden olmaktadır. Çalışma sonuçlarımız literatür bilgisi ve diğer çalışmalara göre değerlendirildiğinde benzerlik göstermemektedir. $\mathrm{Bu}$ durumun mesleki eğitim merkezinde öğrenim gören ergenlerin riskli grupta yer almaları, kural dışı davranış etmenlerine daha fazla maruz kalmalarından kaynaklandığı düşünülmektedir.

Araştırmada mesleki eğitim merkezine devam eden ergenlerin anne babalarının birliktelik durumuna göre kural dışı davranışlarının önemli bir biçimde farklılaşmadığı görülmektedir. Bu durumun mesleki eğitim merkezine devam eden ergenlerin küçük bir örneklem grubunda yer almasından kaynaklandığg düşünülmektedir. Çalışma sonuçlarımızdan farklı olarak literatürde anne-babanın boşanmış olması ya da ölmüş olması da ergenlerde kural dışı davranışlara neden olabileceği belirtilmektedir (Shader 2004; Şahin 2015). Anne baba yoksunluğu olan ergenlerde ruhsal sorunlar ortaya çıkabilmekte ve bu durumlar ergenlerin daha fazla kural dışı davranışı göstermesine neden olabilmektedir (Akduman ve ark. 2007). Çalışma sonuçları incelendiğinde ergenlerin kural dışı davranışlarına yönlenmelerinde anne baba birlikteliğinden çok ebeveynlerin ergene olan davranışlarının önemli olabileceği düşünülmektedir. Ailede duygusal etkileşimin azlığ ergenin yalnızca duygusal gelişimini olumsuz etkilememekte aynı zamanda suça yönelmesinde de etkili olabilmektedir (Ateş ve Akbaş 2012). Literatürde aile ilişkileri uyumlu olan, sağlıklı işlev gösteren ve mutlu aileye sahip ergenlerde suç davranışı düzeylerinin düştüğü belirtilmiştir (Ateş ve Akbaş 2012; Balkaya ve Ceyhan 2007; Ögel 2014).

Ergenlik dönemi, gençlerin riskli davranışları denemeye ve bunların olumsuz sonuçlarına maruz kalmaya çok daha fazla açık oldukları bir dönem olup ergenlik döneminde sık görülen riskli davranışlar, ergenlerin biyolojik, genetik ve kişilik özellikleri ile çevresel etkenlerin etkileşimi sonucunda şekillenmektedir. Son y1llarda ergenlik döneminde görülebilen riskli davranışlardan olan sigara, alkol ve uyuşturucu madde kullanım sıklığında artış olduğunu görülmektedir (Ögel 2014). Literatürde alkol ve uyuşturucu kullanımı ile kural dışı davranışları arasında güçlü bir nedensel bağlantı için yeterli kanıt bulunmamaktadır. Suç işleyen kişiler arasında alkol ve uyuşturucu kullanımı yüksek olabildiği gibi alkol ve uyuşturucu madde temini de suç davranışları görülmesine neden olmaktadır (Korkmaz ve Erden 2010; Ögel 2014). Güngör (2012) risk altındaki çocukların suça yönelim durumlarını belirleyen çalışmalarında ergenlerin \%19'u alkol kullanırken, \%24'ünün madde kullandıkları belirtilmiştir. Özen ve ark. (2005)'nın ergenlerdeki suç davranış durumlarını değerlendirdikleri çalışmalarında ergenlerin 
\%36,4'ünün sigara kullandığı belirtilmiştir. Çalışmamızda kural dışı davranış ölçeğinden elde edilen puan ortalamaları ergenlerin alkol ve uyuşturucu madde kullanma durumlarına göre değerlendirildiğinde istatiksel anlamlılık tespit edilmiştir $(\mathrm{p}<0,05)$. Kural dişı davranış ölçeğinden elde edilen puan ortalamaları ergenlerin sigara kullanma durumlarına göre değerlendirildiğinde aralarında istatiksel olarak anlamlılık saptanmamıştır ( $p>0,05)$. Çalışma sonuçları değerlendirildiğinde ergenlerin alkol ve madde kullanımları arttıkça kural dışı yönelim durumlarında literatürde belirtildiği gibi artış görülmektedir (Çiftçi 2013; Korkmaz ve Erden 2010; Temel 2011). İşyerinde çalışan ergenlerin kendilerini ifade edebilme, bir gruba ait olabilme nedeniyle erişkin davranışı olarak görülen alkol, madde kullanımı, vb. davranışlarını deneyimledikleri düşünülmektedir.

Adölesan döneminde ergenler ebeveynlerinden uzaklaşmaya ve akranlarıyla daha fazla zaman geçirmeye başlarlar. Bu dönemde bir grup tarafından kabul görmeye ve toplumda yer edinebilmeye çalışırlar. Birlikte bulundukları akranları tarafından sürekli duygusal veya ruhsal sağlı̆̆ını tehlikeye sokacak biçimde aşırı sözel tehditlere uğramaları, alay edilmeleri, küçük düşürücü eleştiriler ve yorumlar; bireyin kendisine yönelik algısının ve değerlendirmelerinin olumsuz olmasına neden olacağ 1 için ergenler kendini ispat çabasıyla suça karışabilmektedirler (Akduman ve ark. 2007). Çalışan çocuklar, yaşlarının küçük olması ve deneyimsizlikleri nedeni ile erişkinlere göre daha çok şiddet ve istismar görme riski altındadır. Ergenlik döneminde istismarın sonuçları olarak daha çok suça yönelme durumlarının olduğu belirtilmiştir (Akduman ve Baran 2010; TEPA 2013; Turla, Tomak ve Pekşen 2009). Temel (2011)'in suça yönelmiş çocuklar ile yaptığı çalışmasında ergenlerin \%34'ünün ailelerinden fiziksel şiddete maruz kaldıkları belirtilmektedir. Mesleki eğitim merkezinde eğitim gören ergenler istismar ve kural dışı davranışlara yönelim durumları açısından riskli gruplarda yer almaktadır. Çalışmamızda ölçekten elde edilen puan ortalamaları ergenlerin istismara uğrama durumlarına göre değerlendirildiğinde aralarında istatiksel olarak anlamlılık saptanmamıştır ( $p>0,05)$. Çalışma sonuçla- r1 literatür ile değerlendirildiğinde farklılığın bu dönemdeki ergenlerin istismar durumları ile ilgili doğru bilgilendirme konusunda yetersizliklerinden kaynaklanabileceği düşünülmektedir.

Literatürde yaşları 12 ile 18 arasında değişen çocuk/ ergen suçluların tahliye sonrası 6 yılda yeniden suç işleme durumları yüksek olarak belirtilmiştir (Ögel 2014). Akduman ve ark. (2007)'nın çalışmalarında ergenlerin \%71,9'unun birden fazla suça karıştığı bildirilmişsir. Literatürde riskli, suç içeren, problem, antisosyal davranış olarak adlandırılabilecek kural dışı davranışların daha çok suç işlemiş ya da işlememiş, sslah evinde bulunan/ bulunmayan ergenler üzerinde yapıldığı belirtilmektedir (Bulut 2010). Çalışmamızda çırak olarak çalışan çocukların KDÖ’den elde edilen puan ortalamaları ergenlerin suç işleme durumlarına göre değerlendirildiğinde aralarında istatiksel olarak anlamlılık saptanmamıştır ( $>00,05)$. Çalışma sonuçlarındaki bu farklılık örneklem grubunun küçük olması ve suç işleyenlerin sayısının az almasından kaynaklanmış olabileceği düşünülebilir.

Bireylerin kendilerine özgü birçok tutum, düşünce ve değer aile etkileri ile oluşur. Anne babaları eğitim düzeyine göre sergiledikleri davranışlar ve tutumlar ergenlerin suça karışmasında etkilidir (Akduman ve ark. 2007; Bulut 2010; Ögel 2014; Önder ve Y1lmaz 2012). Literatürde yapılan çalışmalarda ergenlerin anne ve babalarının eğitim düzeyleri artıkça kural dışı yönelim durumlarında artış olduğunu gösteren çalışmalar olduğu gibi (Balkaya ve Ceyhan 2007; Ögel 2014), eğitim düzeyi yükseldikçe ergenlerin kural dışı karışma oranlarının azaldığını gösteren çalışmalarda bulunmaktadır (Akduman ve ark. 2007; Temel 2011). Çalışmamızda ölçekten elde edilen puan ortalamaları ergenlerin anne ve babalarının eğitim durumlarına göre değerlendirildiğinde aralarında istatiksel olarak anlamlılık saptanmamıştır ( $p>0,05)$. Çalışma sonuçlarımız literatür sonuçlarına göre değerlendirildiğinde anne babaların eğitim düzeyleri ile benzerlik görülmemektedir.

Literatürde düşük sosyoekonomik düzeyde yer almak her türlü kural dışı davranış ihtimalini arttırdığı belirtilmektedir (Ögel 2014; Temel 2011; UN 2003). Bulut 
(2010)'un çalışmasında ailenin gelir düzeyi yükseldikçe ergenlerde görülen kural dışı davranışların oranı artmaktadır. Temel (2011)'in çalışmasında ise suç işleme oranı düşük gelir grubundan yüksek gelir grubuna doğru azaldığı görülmektedir. Adli suça karışmış ergenlerin ailesel özelliklerinin araştırıldığı çalışmalar incelendiğinde, genel olarak sosyoekonomik düzeyi düşük ailelerden geldikleri belirtilmektedir (Akduman ve ark. 2007; Ögel 2014; Özen ve ark. 2005). Çalışma sonuçlarımız literatür ve diğer çalışma sonuçlarına göre değerlendirildiğinde ailelerin gelir düzeyi ile aralarında benzerlik görülmemektedir.

\section{SONUÇ VE ÖNERILLER}

Kural dışı davranışlar açısından ergenler bir risk taş1maktadırlar. Mesleki eğitim merkezindeki adölesanların çalışmaları ve diğer adölesanlara göre daha fazla riskli çevrede olmaları nedeniyle büyük bir risk taşıdıkları düşünülen ergenler ile cinsiyet, alkol ve madde kullanımı gibi kişisel değişkenlerin olumsuz etkisinin en aza indirgenebilmesi için önleme çalışmaları yapılmalıdır. Ergenlerde kural dışı davranışların önlenmesi programı farklı disiplin üyelerinin yer aldığı bir yaklaşımla ele alınmalı ve çözüm önerileri tartışılmalıdır.

Çocuk sağlığı hemşirelerinin çocukların gelişim sürecinde önemli bir yere sahip olduğundan, ergenlik döneminde aile ile etkileşimlerine, okul ilişkileri arkadaş ilişkileri, madde alışkanlıkları açısından çocuğu değerlendirmeli ve gerektiğinde öğretmenleri ile iletişime geçerek kural dışı davranışa yönelmesine neden olabilecek risk faktörlerini tanımlamalı ve bu risk faktörlerini ortadan kaldırılması için aile ve okulla işbirliği içinde bulunmalıdır. Özellikle kural dış1 davranışın önlenmesinde aile katılımının sağlanması da çok önemli olduğundan, aileler ergenlik döneminin özellikleri ve sorunları, kural dışı davranış ile ilişkili olabilecek faktörler konusunda bilgilendirilebilir. $\mathrm{Bu}$ nedenle kural dışı davranışını önleyebilmek için öğrencilerin sosyal becerilerini, problem çözme ve iletişim becerilerini, öfke kontrolünü geliştirici çalışmalar düzenlenip; öğretmen, öğrenci ve aile işbirliğini geliştiren çalışmalar arttırılmalıdır.

\section{KAYNAKLAR}

Akduman, G. G., Akduman, B., Cantürk, G. (2007). Ergen suçluluğunda bazı kişisel ve ailesel özelliklerin incelenmesi. Türk Ped Arş, 42(4): 156-161.

Akduman, G. G., Baran, G. (2010). Suça karışan çocuklarda akran istismarının işlediği suçun özellikleri, göç ve okul durumu değişkenleri açısından incelenmesi. Uluslararası Sosyal Araştırmalar Dergisi, 3(14): 33-41.

Arkan, G. (2011). Sanayi sitesinde çalışan çocuk işçilerin çalışma koşulları ve istismara bakışı. Yayınlanmamış Yüksek Lisans Tezi, Gaziantep Üniversitesi Sağlık Bilimleri Enstitüsü, Gaziantep.

Avşar, Z., Öğütoğulları, E. (2012). Çocuk işçiliği ve çocuk işçiliği ile mücadele stratejileri. Sosyal Güvenlik Dergisi, 2(1): 9-40.

Ateş, F. B., Akbaş, T. (2012). Ergenlerde görülen kural dışı davranışların aile işlevselliği ve yaşam kalitesi açısından incelenmesi. Ç. Ü. Sosyal Bilimler Enstitüsü Dergisi, 21(2): 337-352.

Bal, S. (2010). Çocukluk örselenme yaşantıları, ana-baba-ergen ilişki biçimleri ve sosyal destek algısının, kural dışı davranışlarla ilişkisi. Yayınlanmamış Yüksek Lisans Tezi, Çukurova Üniversitesi Sosyal Bilimler Enstitüsü, Adana.

Balkaya, A., Ceyhan, E. (2007). Lise öğrencilerinin suç davranış düzeylerinin bazı kişisel ve ailesel nitelikler bakımından incelenmesi. Aile ve Toplum Eğitim-Kültür ve Araştırma Dergisi, 3(11): 13-28.

Bulut, F. (2010). Ergenlerde görülen kural dışı davranışların aile işlevselliği, aile risk faktörü ve yaşam kalitesi açısından incelenmesi. Yayınlanmamış Yüksek Lisans Tezi, Çukurova Üniversitesi Sosyal Bilimler Enstitüsü, Adana.

Canbulat, N., Yıldız, S. (2011). İstanbul'un Şişli ilçesi'nde gençlerin riskli sağlık davranışları. Hemşirelikte Eğitim ve Araştırma Dergisi, 8(1): 46-52.

Çiftçi, D. B. (2013). Çalışan çocuklarda duygusal ve davranışsal sorunlar: Oto sanayi örneği. Çocuk ve Gençlik Ruh Să̆llğg Dergisi, 20(1): 13-22.

Güler, M. (2010). Sosyal psikoloji bakış açısından çocuk ve ergenlerde suçlu davranış gelişimi. TBB Dergisi, 89(1): 355-372.

Güngör, M. (2013). Risk altındaki çocukların aile yapıları ve suça yönelimleri (Mersin ili örneği). Mersin Üniversitesi Eğitim Fakültesi Dergisi, 9(2): 421-434.

Kaner, S. (2001a). Suç Davranışı Ölçeği Geliştirme Çalışması. 1. Ulusal Çocuk ve Suç: Nedenler ve Önleme Çalışmaları Sempozyumu, 29-30 Mart, Ankara.

Kaner, S. (2001b). Ana Baba Denetimi İle Ergenlerin Suç Kabul Edilen Davranışları Arasındaki İlişkinin İncelenmesi. 1. Ulusal Çocuk ve Suç: Nedenler ve Önleme Çalışmaları Sempozyumu, 29-30 Mart, Ankara. 


\section{Mesleki Ĕ̈itim Merkezine Devam Eden Ergenlerin Kural Dışı Davranış Düzeylerinin İncelenmesi}

Korkmaz, M. N., Erden, G. (2010). Çocukları suç davranışına yönelten olası risk faktörleri. Türk Psikoloji Yazıları, 13(25): 76-87.

Ögel, K. (2014). Çocuk, suç ve bireyselleştirilmiş iyileşme. "Çocuklar için Adalet" Projesi, http://www.cocuklaricinadalet.org/ resources/ckeditor/kcfinder/upload/files/KAYNAK\%20Kitap.pdf (12.12.2014).

Önder, F. C., Yılmaz, Y. (2012). Ortaöğretim öğrencilerinde görülen kuraldışı davranışları yordamada yaşam doyumu ve anne-baba stillerinin rolü. Kuram ve Uygulamada Eğitim Bilimleri, 12(3): 1737-1748.

Özen, S., Ece, A., Oto, R., Tirasçı, Y., Gören, S. (2005). Juvenile delinquency in a developing country: A province example in Turkey. International Journal of Law and Psychiatry, 28(4): 430-441.

Shader, M. (2004). Risk factors for delinquency: An overview, https://www.ncjrs.gov/pdffiles1/ojjdp/frd030127.pdf (12.01.2015).

Şahin, F. Y. (2013). Predicting delinquency levels in Turkish adolescents. Procedia Social and Behavioral Sciences, 89(2013): 841847.
Şahin, F. Y. (2015). Predicting delinquency levels in Turkish adolescents. Hacettepe University Journal of Education, 30(1): 313-323.

Temel, Z. (2011). Suça yönelmiş çocukların aile işlevselliğinin belirlenmesi. Yayınlanmamış Yüksek Lisans Tezi, Cumhuriyet Üniversitesi Sağlık Bilimleri Enstitüsü, Sivas.

TEPA (2013). Türkiye Ergen Profili Araştırması, http://ailetoplum. aile.gov.tr/data/54292ce0369dc32358ee2a46/tepa2013_teksf.pdf (15.12.2014)

Turla, A., Tomak, L., Pekşen, Y. (2009). Çıraklık eğitim merkezine devam eden gençlerin iş yerinde istismara uğrama sıklığı. Turkiye Klinikleri Journal of Pediatrics, 18(3): 167-173.

Türkiye'de Ergen Profili (2008). yeniailetoplum.aile.gov.tr/data/.../ turkiyede_ergen_profili_2008.pdf (15.12.2014).

UN (2003). Juvenile Delinquency World YOUTH Report, www. un.org/esa/socdev/unyin/.../ch07.pdf (12.01.2015).

Wasserman, G. A. ve ark. (2003). Risk and protective factors of child delinquency, https://www.ncjrs.gov/pdffiles1/ojjdp/193409. $\operatorname{pdf}(10.01 .2015)$. 